IS GLOBALIZATION CIVILIZING, DESTRUCTIVE OR FEEBLE? A CRITIQUE OF FIVE KEY DEBATES IN THE SOCIAL-SCIENCE LITERATURE

\author{
Mauro F. Guillén \\ The Wharton School and Department of Sociology \\ University of Pennsylvania \\ 2016 Steinberg Hall-Dietrich Hall \\ Philadelphia, PA 19104-6370 \\ 215-573-6267 \\ guillen@wharton.upenn.edu
}

Annual Review of Sociology

Vol. 27 (2001)

June 2000 Version 


\title{
IS GLOBALIZATION CIVILIZING, DESTRUCTIVE OR FEEBLE? A CRITIQUE OF FIVE KEY DEBATES IN THE SOCIAL-SCIENCE LITERATURE
}

\begin{abstract}
The sociological, economic, political and anthropological literatures are devoting increasing attention to globalization. This chapter discusses the various connotations of the term and puts it in historical perspective. Existing theoretical and empirical research on globalization is organized around five key issues or questions: is it really happening, does it produce convergence, does it undermine the authority of nation-states, is globality different from modernity, and is a global culture in the making? A plea is made for a comparative sociology of globalization that is sensitive to local variations and to how agency, interest and resistance mediate in the relationship between globalization causes and outcomes.
\end{abstract}

Keywords: Globalization; Convergence; Nation-State; Modernity; Global Culture. 
The bulk of the earth must not only be spherical, but not large in comparison with the size of other stars.

—Aristotle (384-322 вс), as quoted by Dreyer (1953:118).

Globalization is one of the most contested topics in the social sciences. Observers and theorists of globalization have variously argued that the rapid increase in cross-border economic, social, technological and cultural exchange is civilizing, destructive or feeble, to borrow Albert Hirschman's (1982) celebrated metaphors. Harold Levitt's “Globalization of Markets" (1983) or Kenichi Ohmae's Borderless World (1990) promise boundless prosperity and consumer joy as a result of globalization, i.e. the global as civilizing. In sharp contrast to this view, the historian Paul Kennedy warns in Preparing for the Twenty-First Century (1993) against our lack of structures to deal with a global world, while political economist Dani Rodrik rings a similar bell of alarm in Has Globalization Gone Too Far? (1997) concerning the increasingly free international economic and financial flows (see also Mittelman 2000). Like in the civilizing view, the destructive interpretation regards globalization as leading to convergence, albeit predicting harmful rather than beneficial consequences. Unlike the adherents to either the civilizing or the destructive views of globalization, some see globalization as a feeble process that has not yet challenged the nation-state and other fundamental features of the modern world, namely, Paul Hirst and Grahame Thompson's Globalization in Question (1996), and Robert Wade's “Globalization and Its Limits" (1996).

In this chapter I first define globalization and its timing. Then, I review the main contributions of the various social sciences to research on globalization, with an emphasis on sociological perspectives. I organize the discussion and critique around five key debates or questions: is globalization really happening, does it produce convergence, does it undermine 
the authority of nation-states, is globality different from modernity, and is a global culture in the making?

\section{WHAT IS GLOBALIZATION?}

Intuitively, globalization is a process fueled by, and resulting in, increasing cross-border flows of goods, services, money, people, information, and culture (Held et al. 1999:16). Sociologist Anthony Giddens (1990:64; 1991:21) proposes to regard globalization as a decoupling or "distanciation" between space and time, while geographer David Harvey (1989) and political scientist James Mittelman (1996) observe that globalization entails a "compression" of space and time, a shrinking of the world. Sociologist Manuel Castells (1996:92) emphasizes the informational aspects of the global economy when he defines it as "an economy with the capacity to work as a unit in real time on a planetary scale." Management scholar Stephen Kobrin (1997:147-148) describes globalization as driven not by foreign trade and investment but by increasing technological scale and information flows. Political scientist Robert Gilpin (1987:389) defines globalization as the "increasing interdependence of national economies in trade, finance, and macroeconomic policy." Sociologist Roland Robertson (1992:8) argues that globalization "refers both to the compression of the world and the intensification of consciousness of the world as a whole." Also sociologist Martin Albrow (1997:88) defines globalization as the "diffusion of practices, values and technology that have an influence on people's lives worldwide." I propose to combine the perspectives of Robertson and Albrow, and define globalization as a process leading to greater interdependence and mutual awareness (reflexivity) among economic, 
political and social units in the world, and among actors in general (Guillén 2001; Held et al. 1999:429-431; Petrella 1996:63-66; Waters 1995:63).

Globalization, however, is also an ideology with multiple meanings and lineages. As Cox (1996) has observed, sometimes it appears loosely associated with neo-liberalism and with technocratic solutions to economic development and reform (Evans 1997; McMichael 1996:177). But the term is also linked to cross-border advocacy networks and organizations defending human rights, the environment, women's rights or world peace (Guidry, Kennedy, and Zald 1999; Keck and Sikkink 1998). The environmental movement, in particular, has raised the banner of globalism in its struggle for a clean planet, as in its "Think Global, Act Local" slogan. Thus, globalization is often constructed as an impersonal and inevitable force in order to justify certain policies or behaviors, however praiseworthy some of them might be. In a broader historical sense, Mazlish (1993:6-7) and Robertson (1992:68-71) cogently argue that not only capitalism or advocacy movements but also Christianity, Islam, and Marxism have made global claims and harbored global pretensions.

The start of globalization is also a contested issue (Held et al. 1999). One could argue that globalization begins with the dawn of history. The literature, however, has tended to date the start of globalization more recently in the experience of the West. At one end of the spectrum, historians have noted the importance of the first circumnavigation of the Earth in 1519-21 (Mazlish 1993). World-system theorists maintain that the expansion of European capitalism in the $16^{\text {th }}$ century marks the start of globalization (Wallerstein 1974; see also Waters 1995:2-4). Some economic historians point to the turn of the century as the heyday of international trade and investment before the convulsions of World War I and the Great Depression threw the world into spiraling protectionism (Williamson 1996). Robertson 
(1992:179) argues that globalization “took off” between 1875 and 1925 with the "time-zoning of the world and the establishment of the international dateline; the near-global adoption of the Gregorian calendar and the adjustable seven-day week; and the establishment of international telegraphic and signaling codes.” Murphy (1994) recounts the history of international organizations to foster transportation and communication since 1850. Students of social movements for the abolition of slavery, woman suffrage, or the prohibition of female circumcision argue that the emergence of contemporary transnational advocacy networks can be traced back to the second half of the $19^{\text {th }}$ century (Keck and Sikkink 1998:41-72).

A third group of scholars starts the analysis of globalization at the end of World War II, with the coming of the nuclear age, the emancipation of colonies, the renewed expansion of trade and investment, and the economic rise of Northeast Asia (Gilpin 1987:341-344; Guillén 2001; Kennedy 1993:47, 50; McMichael 1996). There is also justification to tell the story of globalization beginning with the unraveling of pax americana in the early 1970s or with the rise of neo-liberal ideology in the late 1970s and early 1980s. In a more conceptually informed way, Kobrin (1997:147-148) distinguishes between the trade and investment linkages of $19^{\text {th }}$ century internationalization and the network and information ties of late $20^{\text {th }}$-century globalization (see also Baldwin and Martin 1999; Held et al. 1999). Thus, there is no agreement as to whether it was with Magellan and Mercator, James Watt and Captain Cook, Nixon and Kissinger, or Thatcher and Reagan that globalization started or, to be more precise, that the narrative of globalization ought to begin. Lastly, it should be noted that the English term 'globalization' was first used around 1960 in its world-wide sense as opposed to its much older meanings of the global as something spherical, total or universal (Waters 1995:2). 
Definitions and timing aside, one of the persistent problems afflicting the study of globalization is that it is far from a uniform and inexorable trend. Rather, globalization is a fragmented, incomplete, discontinuous, contingent, and in many ways contradictory and puzzling process (Guidry, Kennedy, and Zald 1999; Held et al. 1999:431). Table 1 presents economic, financial, social, political and bibliographical indicators of globalization. The measures are presented for the 1980-1998 period not because globalization started in 1980 but rather because of data limitations. Foreign direct (excluding portfolio) investment as a percentage of GDP is 2.5 times greater today than twenty years ago — and nearly four times greater in the developing world. Contrary to the conventional wisdom, however, trade in goods or in services has not grown much over the last two decades. Financial globalization, by contrast has grown very rapidly: foreign exchange turnover increased ten-fold between 1979 and 1997 relative to world GDP, and both cross-border bank credit and assets have increased more than two-fold as a percentage of world GDP.

Some key indicators of social exchange across borders are also increasing rapidly, including tourism and international telephone calls (see Table 1). International migration, though on the rise, has not reached important levels relative to world population. Also bucking the globalization trend is the growing number of nation-states: from 157 United Nations members in 1980 to 184 by 1998 . And more ethnic groups than ever seem to be reasserting their identities and yearning to create their own state-Palestinians and Kurds, Basques and Catalans, Scots and Welsh, Tibetans and Kashmiris, Corsicans and Quebecois (Friedman 1994; Geertz 1998; Robertson 1992:98-108; for the dissenting view, see Rapoport 1996). Meanwhile, the number of international organizations has more than trebled. Among international advocacy groups, those concerned with human rights, the environment, 
Esperanto, women's rights and world peace have grown fastest (Keck and Sikkink 1998:11; see also Meyer et al. 1997; Murphy 1994). And the internet has accelerated cross-border exchange during the 1990 s to an extent that is difficult to measure but surely staggering.

It is perhaps ironic to observe that the fastest increase among the indicators included in Table 1 does not refer to globalization itself, but to the literature on globalization. As shown in Figure 1, there has been an explosion in the number of articles on globalization published in the economic, sociological and political literatures. The number of books on globalization has also increased steeply. The historical and anthropological literatures, by contrast, have lagged behind. Among the social sciences, sociology was the first to pay attention to globalization. Sociology journals started to carry large numbers of articles on globalization during the early and mid 1970s, primarily induced by world-system theorizing (Wallerstein 1974). Some authors have attempted to summarize the literature (e.g. Held et al. 1999; Sklair 1991; Waters 1995), and several edited volumes have been compiled (Dunning ed. 1997; Featherstone ed. 1990; Hargittai and Centeno eds. 2001; Mittelman ed. 1996; Sakamoto ed. 1994; Mander and Goldsmith eds. 1996). Perhaps the most bewildering feature of the literature is not its sheer size but the remarkable diversity of authors that have contributed to it, ranging from postmodernist scholars or social theorists who rarely, if ever, engage in empirical research to number-crunching empiricists, politicians, and management consultants.

\section{FIVE KEY DEBATES}

The five key debates that I identify in this chapter are not an exhaustive list of issues in the vast and rich literature on globalization. They capture, however, a broad spectrum of social, political and cultural themes of interest to sociologists and other social scientists. Table 
2 shows how different authors position themselves in the five key debates. One should not assume those on the same side of the fence regarding a particular question actually agree with each other on other issues or that they approach the issue from exactly the same perspective.

\section{Is It Really Happening?}

Most of the books and articles discussed in this chapter simply assume that the world is becoming more global. Myriad policymakers, publicists, and academics take it as axiomatic that globalization is in fact happening without supporting their claim with data (e.g. Ohmae 1990; Naisbitt and Aburdene 1990). Political economist and policymaker Robert Reich (1991), for example, proclaims that "national economies" are disappearing and companies no longer have a nationality; only people do. There are, however, many skeptics.

Perhaps the best-documented case for the feeble argument against globalization has been made by Paul Hirst, an Oxford political scientist with ties to the Labour Party. In a recent book, Hirst and Thompson (1996:1-3, 18-98) argue that the globalization trend of the last twenty years has been overstated as a process: it is not unprecedented in world history, and foreign investment and trade are concentrated in the so-called triad-Western Europe, North America and Japan. In sum, the economy is becoming more international but not more global. Political scientist Robert Wade (1996:66-84) echoes these criticisms: the volume of trade is small relative to the size of most economies (see also Krugman 1994:146-148, 256-267); domestic investment is greater than foreign investment; multinationals locate most of their assets, owners, top managers and R\&D activities in their home countries (see also Doremus et al. 1998); and vast areas of the world have not been affected by globalization, namely, South and Central Asia and the bulk of Africa. 
The feeble argument is useful in that it provides an important corrective to visions and myths of globalization assuming its inevitability and irreversibility. There are, however, two key counterarguments. Regarding the issue of the heterogeneous spread of globalization across the world, Castells (1996:102) correctly observes that the global economy is not meant to encompass the entire Earth. Rather, it comprises only certain segments of activity in both developed and developing countries (see also Kobrin 1997). The second counterargument is that proponents of the feeble thesis focus almost exclusively on the economic and financial aspects of globalization to the detriment of political, social and cultural ones. The literature offers and discuss evidence in support of political and cultural globalization that is, on the whole, quite persuasive (Castells 1996:66-147; Meyer and Hannan 1979; Louch et al. 1998; Petrella 1996:63-66). In addition, global warming, the AIDS pandemic, and the globalization of the media have heightened our awareness of living in an increasingly interconnected world (Held et al. 1999). In sum, scholars arguing the feebleness of globalization have made a contribution in debunking certain myths and assumptions about a process that has all too often been uncritically reified. However, they are perhaps too wedded to a "monolithic" concept of globalization and oblivious to the notion that globality is a network of relationships that creates mutual awareness.

\section{Does It Produce Convergence?}

A second contested issue in the literature on globalization has to do with its consequences as to the convergence of societies towards a uniform pattern of economic, political, and even cultural organization. Most famously expressed in modernization theory, the spread of markets and technology is predicted to cause societies to converge from their 
preindustrial past, although total homogeneity is deemed unlikely. This line of thinking was advanced during the 1950s and 60s by both economists and sociologists (Guillén 2001; Waters 1995:13-15; Albrow 1997:49). Economic historians such as Jeffrey Williamson (1996) have argued and documented convergence in income and labor markets during the $19^{\text {th }}$ century and first decades of the $20^{\text {th }}$. More recently, sociologist Daniel Bell [1973] argued for a technologically driven convergence of postindustrial societies.

Further support for the convergence thesis comes from the "world-society" approach in sociology. In their summaries of an extensive empirical research program on the worldwide spread of educational systems and other forms of state activity, John Meyer and his associates and students argue that the expansion of rationalized state activities has acquired a momentum of its own, largely unaffected by cross-national differences in political structure or economic growth rates. Rather, the diffusion of rationalized systems follows the "exigencies of global social organization whose logic and purposes are built into almost all states.” The result is that "the world as a whole shows increasing structural similarities of form among societies without, however, showing increasing equalities of outcomes among societies" (Meyer and Hannan 1979:3,13-15). Nation-states are seen as exhibiting convergent structural similarity although there is a "decoupling between purposes and structure, intentions and results." World-society researchers argue that conformity comes both from the world-culture of rationalized modernity and from domestic groups that make claims on the state following the "consensus" over the formal acceptance of "matters such as citizen and human rights, the natural world and its scientific investigation, socioeconomic development, and education." They even present evidence to the effect that nationalism and religious fundamentalism "intensify isomorphism more than they resist it" (Meyer et al. 1997:145, 148, 152-154, 161). 
Social and political theorists as well as historians have elaborated a comprehensive critique of the presumed convergent consequences of globalization. Political scientist Robert Cox (1996:28, 30 n. 1) writes that "the social and ethical content of the economy" may be organized differently in various parts of the world." Historian Bruce Mazlish (1993:4) argues that "no single global history is anticipated." Sociologist Anthony Giddens (1990:64, 175) adds an interesting twist when asserting that globalization "is a process of uneven development that fragments as it coordinates. [...] The outcome is not necessarily, or even usually, a generalized set of changes acting in a uniform direction, but consists in mutually opposed tendencies" (see also Held et al. 1999:431, 441). In another book (1991:21-22), Giddens elaborates: "Globalization has to be understood as a dialectical phenomenon, in which events at one pole of a distanciated relation often produce divergent or even contrary occurrences at another.” In a similar vein, anthropologist Jonathan Friedman (1994:210-211) asserts that globalization is the product of cultural fragmentation as much as it is the result of modernist homogeneity, and that "what appears as disorganization and often real disorder is not any the less systemic and systematic."

These social and political theorists, however, have neither engaged in empirical testing of their propositions nor bothered to look for support in the existing literature. There is, though, a considerable body of empirical research backing the antithesis that globalization produces divergence and diversity or at least does not undermine national policies and institutions. Management scholar John Stopford and political economist Susan Strange (1991:1-2) document that the increasingly complex interaction between multinationals and states has produced a divergence in outcomes, while Doremus et al. (1999) show that differentiated national systems of innovation, trade, and investment remain firmly in place. 
Political scientist Geoffrey Garrett (1998:1-4, 10-11, 34-37, 51, 74) has perhaps contributed the most extensive and solid body of empirical evidence, though it refers mostly to the experience of the advanced industrial democracies. He argues and demonstrates empirically that in the context of a global economy at least two paths are possible for national economic and social policymakers: adherence to neoclassical economics or to social democratic corporatism. Garrett's analysis refutes simplistic views about convergence, proposing instead to view the balance of left-right political power and labor market institutions as the two key variables in a contingent analysis of economic performance. The best macroeconomic performance is obtained when the two variables are aligned with each other. For example, redistributive and interventionist policies combine with encompassing labor market institutions to produce macroeconomic performance in terms of growth and unemployment that matches or even surpasses the achievements of laissez-faire policies combined with weak labor market institutions. He concludes that there are "enduring crossnational differences" in economic policymaking and engagement of the global economy. In a broader study encompassing over one hundred countries during the 1985-1995 period, Garrett (1999) finds no convergence in government expenditure patterns as a result of globalization. What has happened over the last decade is that many governments have pursued policies that buffer their citizens from the vagaries of global markets and, in the presence of free capital mobility, willingly and knowingly accepted higher interest rates to keep capital at home.

Students of the varieties of capitalism, mostly political scientists, have long argued that firms and countries pursue different paths of incorporation into the global economy. Thus, German, French, Japanese and American firms are competitive in the global economy, but rarely in the same industry and market segment. German firms excel at high-quality, 
engineering-intensive industries such as advanced machine tools, luxury automobiles, and specialty chemicals (Soskice 1998; Streeck 1991), French firms at large-scale technical undertakings such as high-speed trains, satellite-launching rockets or nuclear power (Storper and Salais 1997:131-148), Japanese firms at most categories of assembled goods, namely, household appliances, consumer electronics and automobiles (Gerlach 1992), and American firms at software, financial services or biotechnology (Storper and Salais 1997:174-188).

Comparative organizational sociologists have also presented qualitative and quantitative evidence to the effect that firms pursue different modes of economic action and adopt different organizational forms depending on the institutional and social structures of their home countries even as globalization increases. Moreover, they have collected data on newly industrialized countries in addition to the most advanced ones. Orrù, Biggart and Hamilton (1996) draw a number of systematic comparisons among East Asian and Western European countries demonstrating that unique national patterns of organization not only persist over time but also contribute to the international competitiveness of firms. Guillén (2001) presents systematic case-study and quantitative evidence demonstrating that firms and labor unions in Argentina, South Korea and Spain diverged in their patterns of behavior, organizational form, and growth even as their home countries became more integrated with the global economy during the post World War II period.

Taken together, the empirical evidence provided by sociologists and political scientists supports well the case for diversity, or at least resilience, in cross-national patterns in the midst of globalization. It must be admitted, however, that world-society researchers also have a point, and one that is well supported by empirical evidence. The reason behind these seemingly irreconcilable empirical results might be that world-society research has made 
measurements at levels of analysis and abstraction higher than the finer-grained analysis of comparative sociologists and political scientists.

It should be noted that some sociologists reject the very terms of the convergence debate by arguing that globalization homogenizes without destroying the local and the particularistic. For example, Viviana Zelizer (1999) argues that "the economy... differentiates and proliferates culturally in much the same way as other spheres of social life do, without losing national and even international connectedness." Thus, globalization is not seen as precluding or contradicting diversity. Like Zelizer, Robertson (1995:34-35) sees the global as the "linking of localities."

A final aspect of the convergence controversy has to do with the impact of globalization on inequality across and within countries. The evidence unambiguously indicates that there is today more inequality across countries than ten, twenty, fifty or even one hundred years ago. Stunningly, the gap in per capita income between rich and developing countries has grown five-fold between 1870 and 1990 (Pritchett 1997; Temple 1999). There are, however, several noteworthy developing countries that have managed to close half or more of the gap since 1960, e.g. South Korea, Taiwan, and Ireland. Very few developing countries, however, have consistently grown faster than the most advanced ones since 1980. Thus, development levels appear not to be converging as a result of globalization. By contrast to cross-national inequality, it is not clear that increased foreign trade and investment during the last twenty years have resulted in substantially higher wage inequality or unemployment within countries. Baldwin and Martin (1999:21) summarize the empirical literature as follows: "Virtually all studies find some impact of trade on the labor market in both the U.S. and Europe. The range of findings, however, is wide. Some find that trade accounted for virtually none of the wage 
gap, while others assigned 100 percent of the gap to trade. The consensus range is perhaps 1020 percent."

In sum, globalization does not seem to compel governments, firms, and individuals to converge in their patterns of behavior. While this may be regarded as a welcome aspect, it is important to bear in mind that increasing globalization has coincided in time with an exacerbation of income disparities across countries, and that at least part of the greater degree of income inequality within countries is due to increased foreign trade and investment.

\section{Does It Undermine the Authority of Nation-States?}

A third key issue surrounding the topic of globalization is whether this process has outgrown the governance structures of the international system of states and undermined the authority of the nation-state. For example, economist Raymond Vernon (1971:249, 265-270, 284) has long argued that the spread of multinational corporations creates "destructive political tensions," and that there is a "need to reestablish balance" between political and economic institutions. Historian Paul Kennedy (1993:53-64, 122-134) asserts that governments are losing control, and that globalization erodes the position of labor and developing countries, and degrades the environment. "Today's global society," he writes, "confronts the task of reconciling technological change and economic integration with traditional political structures, national consciousness, social needs, institutional arrangements, and habitual ways of doing things" (Kennedy 1993:330). In a similar vein, Kobrin $(1997: 157,159)$ argues that globalization challenges both the autonomy or independent decision-making of the state and "raises questions about the meaning of sovereignty in its external sense of a system ordered in terms of mutually exclusive 
territoriality." And Mazlish (1993:4) argues that global history is an attempt to "transcend the nation-state as the focus of history."

Political scientists Yoshikazu Sakamoto $(1994: 19,36)$ and Robert Cox (1996:26-27) concur in arguing that globalization generates problems of international governance and reduce the regulatory power of states. For Rodrik (1997:1-6), globalization creates social and political tensions within and across nation-states. And political theorist Michael Mosher (1999:35) asks, "is there a successful way of reconciling the boundary transgressing character of markets with the boundary maintaining activities of nation-states?" He further notes that globalization has placed two liberal practices-the liberalism of the market and the liberalism of democratic citizenship—on a collision course, raising the dilemma of whether "moral concerns stop at the national border" (Mosher 1999:25).

Sociologists have also joined the chorus of state doomsayers. For Waters (1995:96123), there is an "attenuation of the state," a rise of international organizations, and a trend towards more "fluid" international relations. McMichael (1996:197-207) also sees a decline of the state. For Albrow (1997:164), "the nation-state has failed to confine sociality within its boundaries, both territorial and categorical. The sheer increase in cross-national ties, the diversification of modes of personal relationships and the multiplication of forms of social organization demonstrate the autogenic nature of the social and reveal the nation-state as just another timebound form.” In a more empirically grounded way, Evans (1997:82-87) points out that globalization undermines the state because its associated neo-liberal ideology is against the state and not because globalization is inextricably against the state. He further argues that the state may stage a comeback if there is a "return of the ideological pendulum," or a transformation of the state and a development of new elements of state-society synergy. 
The analysis by British political economist Susan Strange is perhaps the most sophisticated articulation of the position that the international system of nation-states and the nation-state itself are coming under fire in a global world. She writes about the "declining authority of states," and preempts several possible criticisms. First, she argues that state interventionism is on the rise, but in relatively marginal matters. Second, she argues that there are more states in the world, especially after 1989, but that most of the new ones are weak and lack control. Third, she points out that the effectiveness of the East Asian state in orchestrating economic growth was only possible in a post World War II order in which protectionism of the domestic market was acceptable and mature technologies were available (Strange 1996:46). She further observes three power shifts in the global world, namely, from weak to strong states, from states to markets, and from labor markets to financial markets, with some power evaporating or dispersing (Strange 1996:189).

Not surprisingly, those who argue that globalization is a feeble process also maintain that it can be easily handled by nation-states. For example, Hirst and Thompson (1996:143149, 170-194) and Wade (1996) assert that states can cope with globalization, although they have lost some freedom of action, especially concerning financial flows. Feeble proponents, however, are not alone challenging the notion that globalization undermines the nation-state. Macrosociology has long maintained that the global arena is a 'playground' for states, where they compete for economic, military and political supremacy and survival. Thus, the world-system or the international arena, far from threatening states, actually fosters them (Wallerstein 1974; Tilly 1992). Neorealist international relations scholar Robert Gilpin (1987:389-406) points out that globalization has reinforced the importance of domestic policies, as countries engaged in regionalization, sectoral protectionism, and mercantilistic 
competition during the 1980s in response to changes in the international location of activities, resulting in a "mixed system," increasingly globalized and at the same time fragmented (see also Berger 1996:7-21). A related, though distinct, argument against the presumed loss of state power in the wake of globalization comes from political scientist Leo Panitch (1996:84-86). He rightly argues that “today's globalization is authored by states and is primarily about reorganizing rather than bypassing them" (see also Poulantzas 1974:73). Moreover, as Cox (1992:30-31) observes, "power has shifted not away from the state but within the state, i.e. from industry or labor ministries towards economy ministries and central banks."

Another influential political scientist, Saskia Sassen (1996:25-30), maintains that the state does not lose significance. Rather, there is a redefinition of modern features of sovereignty and territoriality, a "denationalizing of national territory." Cox (1987:254-259) argues that globalization induces a transformation of the state, not its diminution. Stopford and Strange (1991:1-2, 97-136) examine the new possibilities for state action in the global economy and conclude that its role has actually become magnified and more complex (see also Held et al. 1999:436-444). According to most political scientists, therefore, the nationstate is alive and well, and the Westphalian order is unlikely to be replaced by a fragmented, Medieval one. A key effect of globalization, however, has been the rise of "global cities"New York, London, Miami, Singapore-whose role and stature transcend the nation-state in which they happen to be located (Choi , Park and Tschoegl 1996; Sassen 1991).

Finally, the world-society view also rejects the claim that globalization undermines nation-states. Noting the expansion of state bureaucracies since World War II, Meyer et al. (1997:157) write that "globalization certainly poses new problems for states, but it also strengthens the world-cultural principle that nation-states are the primary actors charged with 
identifying and managing those problems on behalf of their societies." This argument is strikingly similar to the one offered by Panitch (1996:84-86) and Poulantzas (1974:73). The modern nation-state, world-society scholars conclude, "may have less autonomy than earlier but it clearly has more to do" (Meyer et al. 1997:157).

The question of whether globalization undermines the authority of the nation-state comes best to life when examining the impact of globalization on the viability of the welfare state. Rodrik (1997:49-67) argues that globalization puts downward pressure on government spending for redistribution and welfare, and that the interaction of trade risk and openness calls for more welfare spending, but governments find it harder to find the money, an argument that Vernon (1998:172-175) finds persuasive. Stryker (1998:7-8, 14-15, 17, 32-33) summarizes her assessment of the evidence in that globalization places limits on expansionary policies, represents a loss of power for the working class, and causes welfare state retrenchment. According to these social scientists, the challenge is "to engineer a new balance between market and society, one that will continue to unleash the creative energies of private entrepreneurship without eroding the social basis of cooperation" (Rodrik 1997:85). These arguments have become conventional wisdom among neo-liberal policymakers and journalists. Gloomy, often unsubstantiated, forecasts about the inability of European welfare states to pay for generous social benefits have become commonplace since the early 1980s.

Other political scientists and sociologists, however, see things utterly differently. Political scientist Paul Pierson (1994:1-9) argues that the welfare state has declined not so much as a result of globalization but because of such indirect actions of conservative governments as reductions in the revenue base of the state and attacks on the strength of interest groups, especially labor, an argument that Fligstein (2001) endorses. Garrett (1998:1- 
$2,11,107,132-133,157-158)$ empirically demonstrates the viability of social democratic corporatism even with increasing exposure to globalization in the forms of cross-border trade and capital mobility. He also proves that it is possible to win elections with redistributive and interventionist policies, and that better economic performance in terms of GDP growth and unemployment obtains, though with higher inflation than in the laissez-faire countries (United States, Britain). Garrett (1998:157) concludes that "big government is compatible with strong macroeconomic performance," and that markets do not dominate politics. And in a direct rebuttal of Rodrik (1997), Garrett (1999) analyzes data on more than 100 countries during the 1985-1995 period to find that increasing exposure to globalization does not reduce government spending. Political scientist Evelyne Huber and sociologist John Stephens (1999) echo Garrett's conclusions in that the welfare state is compatible with global capitalism, although they do admit that social democratic policies are today more constrained than in the so-called "golden age" of the 1950s and 60s.

For Garrett, Huber and Stephens, and Fligstein the welfare state is perfectly viable under conditions of globalization. Moreover, it may even be a win-win proposition: it may simultaneously deliver social well-being and enhance international competitiveness. Thus, they reject the tradeoff that neo-liberals see between welfare expenditures and economic competitiveness under conditions of globalization. In spite of the excellent, well-supported research by these authors, however, the debate in the media and among politicians throughout the world remains heavily tilted in favor of those blaming the welfare state for declining competitiveness and various social ills. 


\section{Is Globality Different from Modernity?}

Perhaps the most difficult debate surrounding globalization has to do with whether it is merely a continuation of the trend towards modernity or the beginning of a new era. On one side of the fence, Giddens $(1990: 63,64)$ argues that "modernity is inherently globalizing," and that "globalization [makes] the modes of connection between different social contexts or regions become networked across the earth's surface as a whole." This view follows directly from the concept of "disembedding" or "'the lifting out' of social relations from local contexts of interaction and their restructuring across time and space," which Giddens (1990:21) considers a prerequisite for modernization. World-society scholarship takes sides with Giddens on this point: globalization results in a "sharing" of modernity across the world (Meyer et al. 1997:150, 164).

On the other side of the fence, British social theorist Martin Albrow (1997:4, 33, 95$101,144)$ argues that globalization is a "transformation, not a culmination," and the "transition to a new era rather than the apogee of the old." He proposes a stark distinction between modernity as the imposition of practical rationality upon the rest of the world through the agency of the state and the mechanism of the market, the generation of universal ideas to encompass the diversity of the world," and globality as restoring "the boundlessness of culture and promotes the endless renewability and diversification of cultural expression rather than homogenization or hybridization." Other noted social theorists of globalization also support the same distinction (Robertson 1992:27, 138-145), especially insofar as the modern-nation state is concerned: "The politics of identity substitutes for the politics of nation-building" (McMichael 1996:234). 
The debate over the relationship between modernity and globality is a central one for sociologists. If globality is merely the result of an intensification of modernizing trends, then the recent surge in the number of books and articles on this subject can hardly be justified. There is, however, a key theoretical argument to be made in favor of the view that globality is different from modernity. Modernity — like the distorting Mercator projection-is an outgrowth of the Western worldview. For reasons of theoretical consistency, one should reserve the terms "globalization," "global," and "globality" to denote, respectively, processes, qualities and conditions that are not set into motion or dominated by any one model, paradigm or worldview. In its broadest sense, globality is about a multiplicity of conceptions not about cultural or paradigmatic hegemony; it is about the proliferation of cross-national network ties of an economic, political, social and cultural nature (Guillén 2001; Held et al. 1999). This criticism is especially germane in the case of authors who consider globalization to be an inevitable and sweeping process—neo-liberals and Marxists in particular-as Fligstein (2001) has aptly pointed out.

Finally, Kobrin (1997:147-148) has proposed a distinction between globalization in the late $20^{\text {th }}$ century and the previous period of "modern" expansion of the world economy that is useful empirically. The "international" economy of the $19^{\text {th }}$ century "links discrete, mutually exclusive, geographical national markets through cross-border flows of trade and investment." By contrast, the "global" economy of the late $20^{\text {th }}$ century is driven by the increasing scale of technology, the surge in cross-border collaboration of firms along the value-added chain, and the cross-border integration of information flows. Thus, globalization has "substantive meaning" because, this time around, "national markets are fused transnationally rather than linked across borders" (Kobrin 1997:148; see also Held et al. 1999:429-431). 


\section{Is a Global Culture in the Making?}

Perhaps the most popular and controversial of the debates about globalization has to do with the rise of a global culture. Actually, there are only a few scholars who maintain that a global culture is in the making. The idea goes back to Marshall McLuhan's slippery concept of the "global village" (McLuhan 1964; McLuhan and Fiore 1967), later picked up by some influential marketing researchers (Levitt 1983) who argued that the world was becoming increasingly populated by cosmopolitan consumers. Sociologist Leslie Sklair (1991:75-81) writes that a "culture-ideology of consumerism"-driven by symbols, images, and the aesthetic of the lifestyle and the self-image-has spread throughout the world and is having some momentous effects, including the standardization of tastes and desires, and even the fall of the Soviet order.

Other sociologists, however, argue against the homogenizing effects of mass consumerism. Zelizer (1999) writes that consumer differentiation should not be confused with segregation, and posits that in the U.S. economy differentiation is combined with connection: "the same consumer product can have at the same moment universal and local meaning." Zelizer urges sociologists to distinguish between the phenomenon of worldwide diffusion and the experience at the receiving end, which seems to be growing more diverse even as globalization intensifies (see also Held et al. 1999:374). Similarly, anthropologist Arjun Appadurai $(1996: 4,21)$ argues that "individuals and groups seek to annex the global into their own practices of the modern," and that "consumption of the mass media worldwide provokes resistance, irony, selectivity, and, in general, agency." Using cross-national attitudinal data over the 1981-98 period, Inglehart and Baker (2000) find that national cultures and values 
change over time, though in "path-dependent" rather than convergent ways. Even worldsociety arguments about the "world culture of educated individual choice and responsibility" (Meyer and Hannan 1979:3) stop short of announcing a global culture à la McLuhan.

However, they do describe world-culture as binding society and individuals together "by rationalized systems of (imperfectly) egalitarian justice and participatory representation, in the economy, polity, culture, and social interaction" (Meyer et al. 1997:162). Other researchers have found that the spread of the mass media is not enough to account for the rise of crossborder advocacy groups (Keck and Sikkink 1998:32-34, 210-211), although “global governance" of major aspects of cross-border communication has been on the rise since 1850 (Murphy 1994).

Political and social theorists and historians have noted the rise of what modernists would call "particularistic" identities as evidence against the rise of a global culture. Cox (1996:27) writes about globalization producing a "resurgent affirmation of identities," while Waters (1995:124-157) contrasts a cultural and "religious mosaic" with global cultural production and consumption of music, images and information. Mazlish (1993:14) notes that "ethnic feeling is a powerful bond," and skeptically asks, "what counterpart can there be on the global level?" Political scientist Deborah Yashar (1999) rejects "global culture” and "global citizenship" concepts but also finds fault with the argument that globalization has induced the proliferation of ethnic movements. In her comparison of indigenous movements in Latin America, Yashar clearly demonstrates that no aspect of globalization-economic, political, social or normative-can account for the rise of ethnic-based activism since the 1960s. Rather, globalization changes the characteristics of the states that activists face when making their claims. 
Cross-border migration creates an unusually rich laboratory for assessing the rise of a global culture. Sociologist Alejandro Portes (1997:3) proposes the term "transnational communities" to refer to cross-border networks of immigrants that are "'neither here nor there' but in both places simultaneously" (see also Portes, Guarnizo, and Landolt 1999). Different transnational communities, however, exhibit different origins, features and problems, and certainly do not form a monolithic global class of cosmopolitan citizens. Similarly to Portes, Friedman (1994) accepts the basic notion of cultural fragmentation proposed by Appadurai, Smith and Zelizer, but argues that in today's world the existence of tribal societies cannot be correctly understood without explaining how they are embedded in global networks. In his view, cultural diversity must be seen in a global context.

Some of the most persuasive arguments against the idea of the emergence of a global culture come from anthropologist Clifford Geertz. He observes that the world is "growing both more global and more divided, more thoroughly interconnected and more intricately partitioned at the same time $[\ldots]$ Whatever it is that defines identity in borderless capitalism and the global village it is not deep going agreements on deep going matters, but something more like the recurrence of familiar divisions, persisting arguments, standing threats, the notion that whatever else may happen, the order of difference must be somehow maintained" (Geertz 1998:107-110). Like Geertz, sociologist Anthony Smith is skeptical, and notes an interesting "initial problem" with the concept of 'global culture': "Can we speak of 'culture' in the singular? If by 'culture' is meant a collective mode of life, or a repertoire of beliefs, styles, values and symbols, then we can only speak of cultures, never just culture; for a collective mode of life $[\ldots]$ presupposes different modes and repertoires in a universe of 
modes and repertoires. Hence, the idea of a 'global culture' is a practical impossibility, except in interplanetary terms" (Smith 1990:171).

The ultimate question about the alleged rise of a global culture has to do with whether a global language is emerging. The diffusion of Esperanto has certainly not delivered on early expectations, and the "English-as-global-language" argument seems equally far-fetched and indefensible. As Mazlish (1993:16) observes, English "is becoming a sort of lingua franca [but] there are serious limitations to the use of English as the daily language of a global culture." Moreover, English is being challenged as the dominant language in parts of the United States and the United Kingdom. It is also instructive to recall that the most successful world language ever, Latin, evolved into a mosaic of Romance languages after spreading in its various vulgarized forms throughout Western and Central Europe, Northwestern Africa and Asia Minor. Smith (1990:185-186) notes that, rather than the emergence of a 'global' culture held together by the English language, what we are witnessing is the emergence of 'culture areas' - not necessarily at odds or in conflict with each other, as Huntington (1996) would have it. Thus, Spanish, Russian, Arabic, French, Kiswahili and Chinese have become the shared languages of certain groups, communities or population strata across countries located in specific regions of the world, namely, Latin America, the CIS, the Arab world, Subsaharan Africa, East Africa, and South East Asia, respectively.

\section{TOWARD A COMPARATIVE SOCIOLOGY OF GLOBALIZATION}

The social-science literature on globalization contains important theoretical and empirical disagreements. Scholars have provided very different answers to the five key debates discussed in this chapter. The balance of opinion appears to be tilted, however. Most 
research either assumes or documents that globalization is indeed happening, and most empirical studies—with the notable exception of the world-society approach—do not find convergence in political, social or organizational patterns as a result of globalization. The most persuasive empirical work to date indicates that globalization per se neither undermines the nation-state nor erodes the viability of the welfare state. Finally, there is more support for the arguments that globality is different from modernity and that no such thing as a global culture is emerging.

Relative to the other social sciences, sociology has contributed to the debate over globalization in three important ways. First, social theorists have developed an understanding of the nature and epochal implications of globalization. Although there is no agreement as to whether globalization is a continuation of modernity or not, there is an incipient body of work that outlines in detail what are the main theoretical perspectives and problems. Moreover, sociologists have called the attention to the cultural, reflexive and aesthetic aspects of globalization in addition to its economic and political dimensions (Albrow 1997; Castells 1996; Giddens 1990, 1991; Guillén 2001; Robertson 1992; Sklair 1991; Waters 1995). Second, world-society scholars have developed a macrophenomenological approach to globalization and the nation-state based on a sound institutional theoretical foundation, and supported their view with systematic empirical evidence encompassing the entire world (Meyer and Hannan 1979; Meyer et al. 1997). Third, comparative sociologists have theorized about cross-national difference and similarity, and how they are affected by globalization. They have also offered empirical evidence in the forms of both rich case studies and quantitative analyses (Guillén 2001; Orrù, Biggart and Hamilton 1996). Sociologists, however, need to continue reading the important contributions that economic historians, 
management scholars, political scientists and anthropologists are making to the theoretical and empirical study of such a complex and multifaceted phenomenon as globalization.

The analysis and critique presented in this chapter indicates that globalization, far from being a feeble phenomenon, is changing the nature of the world. However, it is neither an invariably civilizing force nor a destructive one. Although further empirical investigation is warranted, there is already enough evidence available to reject either extreme (Held et al. 1999). Globalization is neither a monolithic nor an inevitable phenomenon. Its impact varies across countries, societal sectors, and time. It is contradictory, discontinuous, even haphazard. Therefore, one needs to be open-minded about its unexpected and unintended consequences. One also needs to take into account the role that agency, interest and resistance play in shaping it. As Pieterse (1996:556) has pointed out, globalization does not necessarily pose a choice between condemnation and celebration. Rather, it begs to be engaged, comprised, given form (Geertz 1998).

The complexity of globalization certainly invites additional research. We are in great need of further theoretical work to clarify the economic, political, cultural and aesthetic dimensions of globalization, and how they interact with each other. We also lack theoretical perspectives that bridge the micro-macro gap, i.e. that move across levels of analysis from the world-system to the nation-state, the industry, sector, community, organization, and group. Many of the empirical disagreements in the literature are primarily due to the various levels of analysis at which different researchers operate. Understanding globalization will require us to gather more and better data about its myriad manifestations, causes, and effects. We still know very little about what exactly causes it and what are its consequences on such key sociological variables as organizational patterns, authority structures, social inequality, and social 
movements, to name but a few. And sociologists need to work hard on government agencies and other data-gathering organizations so that they pay more attention in their surveys and censuses to relationships at various levels of aggregation.

Given the infancy of our efforts to understand globalization and the complexity of the phenomenon, it seems sensible to ask not only for an intensification of our interdisciplinary awareness but also for a comparative approach to the sociology of globalization. Comparing lies at the heart of the sociological enterprise (Smelser 1976; Tilly 1984). We need to engage in comparative work in the dual sense of using multiple methods of data collection and analysis, and of applying our theoretical and empirical tools to a variety of research settings defined at various levels of analysis. The differences and similarities across such settings ought to give us a handle on the patterns according to which the causes and effects of globalization change from one setting to another. Without a comparative approach, the literature on globalization promises to remain as puzzling and contradictory as the phenomenon itself.

\section{ACKNOWLEDGMENTS}

A grant from the Jones Center at the Wharton School funded this research. I thank Howard Aldrich, Miguel Ángel Centeno, Randall Collins, Paul DiMaggio, Geoffrey Garrett, Clifford

Geertz, Eszter Hargittai, Vit Henisz, Albert Hirschman, Evelyne Huber, John Kimberly, Steve Kobrin, Bruce Kogut, John Meyer, Marshall Meyer, James Mittelman, Walter Powell, John Stephens, Sandra Suárez, Gabriel Szulanski, Adrian Tschoegl, and Viviana Zelizer for helpful comments and/or for providing me with various references, information and sources. I am also grateful to my Work-Study research assistants Anne Chun, Yi Jun, and Gina Mok. 


\section{REFERENCES}

Albrow M. 1997. The Global Age. Stanford, CA: Stanford University Press.

Appadurai A. 1996. Modernity at Large: Cultural Dimensions of Globalization. Minneapolis: University of Minnesota Press.

Baldwin RE, Martin P. 1999. Two Waves of Globalization: Superficial Similarities, Fundamental Differences. NBER Working Paper Series 6904. Cambridge, MA: National Bureau of Economic Research.

Bell D. [1973] 1976. The Coming of Post-Industrial Society. New York: Basic Books.

Berger S. 1996. Introduction. In National Diversity and Global Capitalism, ed. S Berger, R Dore, 1-25. Ithaca, NY: Cornell University Press.

Boyer R. 1996. The Convergence Hypothesis Revisited: Globalization but Still the Century of Nations? In National Diversity and Global Capitalism, ed. S Berger and R Dore, 29-59. Ithaca, NY: Cornell University Press.

Castells M. 1996. The Rise of the Network Society. Cambridge, MA: Blackwell.

Choi SR, Park D, Tschoegl AE. 1996. Banks and the World's Major Banking Centers, 1990. Weltwirtschaftliches Archiv 132 (4):774-793.

Cox, RW. 1987. Production, Power and World Order: Social Forces in the Making of History. New York: Columbia University Press.

Cox, RW. 1992. Global Perestroika. In New World Order? The Socialist Register 1992, ed. R Miliband, L Panitch, 26-43. London: Merlin.

Cox, RW. 1996. A Perspective on Globalization. In Globalization: Critical Reflections, ed. JH Mittelman, 21-30. Boulder: Lynne Rienner Publishers. 
Doremus PN, Keller WW, Pauly LW, Reich S. 1998. The Myth of the Global Corporation. Princeton, NJ: Princeton University Press.

Dreyer JLE. 1953. A History of Astronomy from Thales to Kepler. New York: Dover.

Dunning JH, ed. 1997. Governments, Globalization, and International Business. New York: Oxford University Press.

Evans P. 1997. The Eclipse of the State? World Politics 50:62-87.

Featherstone M, ed. 1990. Global Culture. London: Sage.

Fligstein N. 2001. Is Globalization the Cause of the Crises of Welfare States? In The Architecture of Markets. Princeton, NJ: Princeton University Press.

Friedman J. 1994. Cultural Identity and Global Process. London: Sage.

Garrett G. 1998. Partisan Politics in the Global Economy. New York: Cambridge University Press.

Garrett G. 1999. Trade, Capital Mobility and Government Spending Around the World. Working Paper, Department of Political Science, Yale University.

Geertz C. 1973. The Interpretation of Cultures: Selected Essays. New York: Basic.

Geertz C. 1998. The World in Pieces: Culture and Politics at the End of the Century. Focaal: Tijdschrift voor Antropologie 32:91-117.

Gerlach ML. 1992. Alliance Capitalism: The Social Organization of Japanese Business. Berkeley, CA: University of California Press.

Giddens A. 1990. The Consequences of Modernity. Stanford, CA: Stanford University Press. Giddens A. 1991. Modernity and Self-Identity. Cambridge, MA: Polity Press. Gilpin R. 1987. The Political Economy of International Relations. Princeton, NJ: Princeton University Press. 
Guidry JA, Kennedy MD, Zald MN. 1999. Globalizations and Social Movements. In Globalizations and Social Movements: Culture, Power, and the Transnational Public Sphere.

Guillén MF. 2001. The Limits of Convergence: Globalization and Organizational Change in Argentina, South Korea, and Spain. Princeton, NJ: Princeton University Press.

Hargittai E, Centeno MA, eds. 2001. Mapping Globalization. American Behavioral Scientist, in press.

Harvey D. 1989. The Condition of Postmodernity. Oxford: Blackwell.

Held D, McGrew A, Goldblatt D, Perraton J. 1999. Global Transformations. Stanford, CA: Stanford University Press.

Hirschman AO. 1982. Rival Interpretations of Market Society: Civilizing, Destructive, or Feeble? Journal of Economic Literature 20:1463-1484.

Hirst P, Thompson G. 1996. Globalization in Question. London: Polity.

Huber E, Stephens JD. 1999. Welfare State and Production Regimes in the Era of Retrenchment. Occasional Papers No. 1, School of Social Science, Institute for Advanced Study, Princeton, New Jersey.

Huntington SP. 1996. The Clash of Civilizations and the Remaking of World Order. New York: Simon \& Schuster.

Inglehart R, Baker WE. 2000. Modernization, Cultural Change, and the Persistence of Traditional Values. American Sociological Review, 65:19-51.

Janos AC. 1997. Paradigms Revisited: Productionism, Globality, and Postmodernity in Comparative Politics. World Politics 50 (October):118-149. 
Keck ME, Sikkink K. 1998. Activists Beyond Borders: Advocacy Networks in International Politics. Ithaca, NY: Cornell University Press.

Kennedy P. 1993. Preparing for the Twenty-First Century. New York: Random House.

Kobrin SJ. 1997. The Architecture of Globalization: State Sovereignty in a Networked Global Economy. In Governments, Globalization, and International Business, ed. JH Dunning, 146-171. New York: Oxford University Press.

Krugman P. 1994. Peddling Prosperity. New York: W. W. Norton.

Levitt T. 1983. The globalization of markets. Harvard Business Review 61(3):92-102.

Louch H, Hargittai E, Centeno MA. 1998. Who Calls Whom? Networks and Globalization. Paper presented at the Annual Meetings of the American Sociological Association, San Francisco.

McLuhan M. 1964. Understanding Media. London: Routledge.

McLuhan M, Fiore Q. 1967. The Medium is the Message. London: Allen Lane.

McMichael P. 1996. Development and Social Change: A Global Perspective. Thousand Oaks, CA: Pine Forge Press.

Mander J, Goldsmith E eds. 1996. The Case Against the Global Economy. San Francisco: Sierra Club Books.

Mazlish B. 1993. An Introduction to Global History. In Conceptualizing Global History, B Mazlish, R Buultjens, 1-24. Boulder, CO: Westview Press.

Meyer JW, Boli J, Thomas GM, Ramirez FO. 1997. World Society and the Nation-State. American Journal of Sociology 103(1):144-181.

Meyer JW, Hannan MT. 1979. National Development in a Changing World System: An Overview. In National Development and the World System: Educational, Economic, and 
Political Change, 1950-1970, ed. JW Meyer, MT Hannan, 3-16. Chicago: The University of Chicago Press.

Mittelman JH. 1996. The Dynamics of Globalization. In Globalization: Critical Reflections, ed. JH Mittelman, 1-19. Boulder: Lynne Rienner Publishers.

Mittelman JH. 2000. The Globalization Syndrome: Transformation and Resistance. Princeton, NJ: Princeton University Press.

Mittelman JH, ed. 1996. Globalization: Critical Reflections. Boulder: Lynne Rienner Publishers.

Mosher M. 1999. Border Patrols and Border Crossings: The Seductions of Globalization. Manuscript.

Murphy CN. 1994. International Organization and Industrial Change: Global Governance since 1850. New York: Oxford University Press.

Naisbitt J, Aburdene P. 1990. Megatrends 2000. New York: Morrow.

Ohmae K. 1990. The Borderless World. New York: Harper Business.

Orrù M, Biggart NW, Hamilton GG. 1997. The Economic Organization of East Asian Capitalism. Thousand Oaks, CA: Sage.

Panitch L. 1996. Rethinking the Role of the State. In Globalization: Critical Reflections, ed. JH Mittelman, 83-113. Boulder: Lynne Rienner Publishers.

Petrella R. 1996. Globalization and Internationalization. In $\underline{\text { States against Markets: The Limits }}$ of Globalization, ed. R Boyer, D Drache, 62-83. London: Routledge.

Pierson P. 1994. Dismantling the Welfare State? Reagan, Thatcher, and the Politics of Retrenchment. New York: Cambridge University Press. 
Pieterse JN. 1996. The Development of Development Theory: Towards Critical Globalism. Review of International Political Economy 3(4):541-564.

Pritchett L. 1997. Divergence, Big Time. Journal of Economic Perspectives 11(3):3-17.

Portes A. 1997. Globalization from Below: The Rise of Transnational Communities. Working Paper 98-08. Princeton, NJ: Center for Migration and Development.

Portes A, Guarnizo LE, Landolt P. 1999. The Study of Transnationalism: Pitfalls and Promise of an Emergent Research Field. Ethnic and Racial Studies 22 (2):217-237.

Poulantzas N. 1974. Classes in Contemporary Capitalism. London: New Left Books.

Rapoport DC. 1996. The Importance of Space in Violent Ethno-Religious Strife. Nationalism \& Ethnic Politics 2(2):258-285.

Reich RB. 1991. The Work of Nations. New York: Alfred A. Knopf.

Robertson R. 1992. Globalization: Social Theory and Global Culture. London: Sage Publications.

Robertson R. Glocalization: Time-Space and Homogeneity-Heterogeneity. In Global Modernities, ed. M Featherstone, S Lash, R Robertson, 25-44. London: Sage.

Rodrik D. 1997. Has Globalization Gone too Far? Washington, DC: Institute for International Economics.

Sakamoto Y. 1994. A Perspective on the Changing World Order: A Conceptual Prelude. In Global Transformation, ed. Y Sakamoto, 15-54. New York: United Nations University Press.

Sakamoto Y, ed. 1994. Global Transformation. New York: United Nations University Press. Sassen S. 1991. The Global City. Princeton, NJ: Princeton University Press. 
Sassen S. 1996. Losing Control? Sovereignty in an Age of Globalization. New York:

Columbia University Press.

Sklair L. 1991. Sociology of the Global System. New York: Harvester Wheatsheaf.

Smelser NJ. 1976. Comparative Methods in the Social Sciences. Englewood Cliffs, NJ:

Prentice-Hall.

Smith AD. 1990. Towards a Global Culture? Theory, Culture \& Society 7:171-191.

Soskice D. 1998. Divergent Production Regimes: Coordinated and Uncoordinated Market

Economies in the 1980s and 1990s. In Continuity and Change in Contemporary

Capitalism, ed. H Kitschelt, 101-134. New York: Cambridge University Press.

Stopford JM, Strange S. 1991. Rival States, Rival Firms. New York: Cambridge University

Press.

Storper M, Salais R. 1997. Worlds of Production: The Action Frameworks of the Economy.

Cambridge, MA: Harvard University Press.

Strange, S. 1996. The Retreat of the State: The Diffusion of Power in the World Economy.

New York: Cambridge University Press.

Streeck W. 1991. On the Institutional Conditions of Diversified Quality Production. In

Beyond Keynesianism: The Socio-Economics of Production and Full Employment, ed. E.

Matzner and W. Streeck, 12-61. Hants, England: Edward Elgar Publishing.

Stryker R. 1998. Globalization and the Welfare State. International Journal of Sociology and

Social Policy 18(2-4):1-49.

Temple J. 1999. The New Growth Evidence. Journal of Economic Literature 37:112-156.

Tilly C. 1984. Big Structures, Large Processes, Huge Comparisons. New York: Russell Sage Foundation. 
Tilly C. 1992. Coercion, Capital, and European States, A.D. 990-1992. Cambridge: Basil Blackwell.

Tschoegl AE. 1998. Country and Bank Sources of International Competitiveness: The Case of the Foreign Exchange Market. Paper, The Wharton School of the University of Pennsylvania.

Vernon R. 1971. Sovereignty at Bay: The Multinational Spread of U.S. Enterprises. New York: Basic Books.

Vernon R. 1998. In the Hurricane's Eye: The Troubled Prospects of Multinational Enterprises. Cambridge, MA: Harvard University Press.

Wade R. 1996. Globalization and Its Limits: Reports of the Death of the National Economy are Greatly Exagerated. In National Diversity and Global Capitalism, ed. S Berger, R Dore, 60-88. Ithaca, NY: Cornell University Press.

Wallerstein I. 1974. The Modern World-System. New York: Academic Press.

Waters M. 1995. Globalization. New York: Routledge.

Western B. 1997. Between Class and Market: Postwar Unionization in the Capitalist Democracies. Princeton, NJ: Princeton University Press.

Williamson JG. 1996. Globalization, Convergence, History. Journal of Economic History 56(2):277-306.

Yashar DJ. 1999. Citizenship Claims and Indigenous Movements: Contentious Politics in an Age of Globalization. Paper. Department of Politics, Princeton University.

Zelizer VA. 1999. Multiple Markets: Multiple Cultures. In Diversity and Its Discontents: Cultural Conflict and Common Ground in Contemporary American Society, ed. NJ Smelser, J Alexander, 193-212. Princeton, NJ: Princeton University Press. 
Table 1: Indicators of Globalization, 1980-1998

\begin{tabular}{|c|c|c|c|c|c|}
\hline Indicators: & 1980 & 1985 & 1990 & 1995 & 1998 \\
\hline \multicolumn{6}{|l|}{ A. Economic: } \\
\hline Inward foreign direct investment stock, $\%$ world GDP & 4.6 & 6.5 & 8.0 & 10.1 & $11.7^{\mathrm{h}}$ \\
\hline Developed countries, \% GDP & 3.8 & 4.9 & 6.6 & 9.1 & $10.5^{\mathrm{h}}$ \\
\hline Developing countries, \% GDP & 4.3 & 8.2 & 8.5 & 15.4 & $16.6^{\mathrm{h}}$ \\
\hline Gross value added of foreign affiliates, $\%$ world GDP & $\ldots$ & 5.2 & 6.4 & 6.3 & $7.8^{\mathrm{h}}$ \\
\hline Exports of foreign affiliates, $\%$ total world exports & $\ldots$ & 31.9 & 27.5 & 32.3 & 35.6 \\
\hline Exports + imports of goods, $\%$ world non-service GDP & 71.7 & 68.3 & 74.3 & 80.4 & ... \\
\hline Developed countries, \% non-service GDP & 76.9 & 72.8 & 81.4 & 81.6 & \\
\hline Developing countries, $\%$ non-service GDP & 55.5 & 52.1 & 46.7 & 75.2 & $79.6^{\mathrm{h}}$ \\
\hline Exports + imports of goods $\&$ services, $\%$ world GDP & 40.0 & 38.9 & 38.7 & 42.9 & $\ldots$ \\
\hline Developed countries, \% GDP & 40.9 & 40.0 & 38.7 & 41.7 & $\ldots$ \\
\hline Developing countries, \% GDP & 36.8 & 34.2 & 38.8 & 48.1 & $\ldots$ \\
\hline \multicolumn{6}{|l|}{ B. Financial: } \\
\hline Daily currency exchange turnover, $\%$ world GDP ${ }^{\mathrm{a}}$ & 0.7 & 1.3 & 3.8 & 5.6 & 6.8 \\
\hline Cross-border bank credit stock, $\%$ world GDP ${ }^{\mathrm{b}}$ & 13.9 & 19.9 & 34.3 & 33.1 & .. \\
\hline Cross-border banking assets, $\%$ world GDP ${ }^{\mathrm{b}}$ & 13.7 & 19.9 & 28.1 & 28.5 & $\cdots$ \\
\hline \multicolumn{6}{|l|}{ C. Social \& Political: } \\
\hline International tourist arrivals, $\%$ world population & 3.5 & 6.7 & 8.6 & 9.9 & $\ldots$ \\
\hline Stock of international migrants, $\%$ world population ${ }^{\mathrm{c}}$ & 1.5 & 1.8 & 2.0 & 2.2 & . \\
\hline International calls, minutes per million $\$$ world GDP $^{\mathrm{d}}$ & $\ldots$ & 1354 & 1600 & 2174 & \\
\hline Internet hosts, number (thousands) ${ }^{\mathrm{e}}$ & 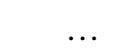 & 5 & 617 & 12881 & $19459^{\mathrm{h}}$ \\
\hline Nation-states with membership in the United Nations & 157 & 157 & 159 & 184 & 184 \\
\hline International organizations, number & $14273^{\mathrm{g}}$ & 24180 & 26656 & 41722 & 48350 \\
\hline \multicolumn{6}{|l|}{ D. Bibliographical: } \\
\hline \multicolumn{6}{|l|}{ Literature on globalization, annual entries ${ }^{\mathrm{f}}$ : } \\
\hline Sociological Abstracts & 89 & 142 & 301 & 1068 & 1009 \\
\hline Econlit & 19 & 269 & 608 & 1044 & 924 \\
\hline PAIS (Politics \& International Relations) & 64 & 101 & 309 & 366 & 698 \\
\hline Historical Abstracts & 69 & 81 & 103 & 166 & 157 \\
\hline Anthropological Literature & 6 & 2 & 6 & 16 & 34 \\
\hline Books in Print & 48 & 92 & 328 & 689 & 589 \\
\hline
\end{tabular}

Notes:

${ }^{\mathrm{a}}$ Data are for 1979, 1984, 1989, 1995, and 1998.

${ }^{\mathrm{b}}$ Data are for 1981, 1986, 1991 and 1995.

${ }^{\mathrm{c}}$ Estimates.

${ }^{\mathrm{d}}$ Excludes international calls using cellular phones or private networks.

${ }^{\mathrm{e}}$ Data are for 1986, 1991, 1996, and 1997.

"Articles or books with the words "global" or "globalization" in the title, subject heading or abstract.

g 1981 .

${ }^{\mathrm{h}} 1997$.

Sources: World Investment Report; International Trade Statistics Yearbook; UN Statistical Yearbook;

Baldwin and Martin (1999:12); Tschoegl (1998); Vernon (1998:198); Miguel Centeno, Department of Sociology, Princeton University; Yearbook of International Organizations; Penn Library Databases. 
Table 2: Five Key Debates about Globalization

\begin{tabular}{|c|c|c|}
\hline \multirow[b]{2}{*}{ Debate: } & \multicolumn{2}{|c|}{ Answers in the Literature: } \\
\hline & Yes & No \\
\hline $\begin{array}{l}\text { 1. Is It Really } \\
\text { Happening? }\end{array}$ & $\begin{array}{l}\text { Meyer and Hannan } 1979 \\
\text { Naisbitt and Aburdene } 1990 \\
\text { Ohmae 1990 } \\
\text { Castells 1996:66-147 } \\
\text { Rodrik 1997:9 } \\
\text { Held et al. } 1999\end{array}$ & $\begin{array}{l}\text { Krugman 1994:146-148, 256-267 } \\
\text { Berger 1996:7-8, 11, 19-21 } \\
\text { Hirst and Thompson 1996:1-3, 18-98 } \\
\text { Wade 1996:66-84 } \\
\text { Doremus et al. } 1998 \\
\text { Fligstein 2001 }\end{array}$ \\
\hline $\begin{array}{l}\text { 2. Does It } \\
\text { Produce } \\
\text { Convergence? }\end{array}$ & $\begin{array}{l}\text { Bell [1973] } \\
\text { Meyer and Hannan 1979:13-15 } \\
\text { Levitt } 1983 \\
\text { Williamson } 1996 \\
\text { Meyer et al. 1997:145, 148, 152-154, } 161\end{array}$ & $\begin{array}{l}\text { Giddens 1990:63-64, 1991:21-22 } \\
\text { Stopford and Strange 1991:1-2 } \\
\text { Robertson 1992:27, } 145 \\
\text { Friedman 1994:210-211 } \\
\text { Berger 1996:2-7, 19-21 } \\
\text { Boyer 1996:33, 58 } \\
\text { Cox 1996:28, 30 n. 1 } \\
\text { Albrow 1997:86, 144, 149, 189 } \\
\text { Garrett 1998:1-11, 34-37, 51, 74, } 1999 \\
\text { Held et al. 1999:431, 441 } \\
\text { Guillén 2001 }\end{array}$ \\
\hline $\begin{array}{l}\text { 3. Does It } \\
\text { Undermine the } \\
\text { Authority of } \\
\text { Nation-States? }\end{array}$ & $\begin{array}{l}\text { Vernon 1971:249-258, 1998:172-175 } \\
\text { Kennedy 1993:53-64, 122-134, } 330 \\
\text { Mazlish 1994:4 } \\
\text { Sakamoto 1994:19, } 36 \\
\text { Waters 1995:96-123 } \\
\text { Cox 1996:26-27 } \\
\text { McMichael 1996:197-207 } \\
\text { Mander \& Goldsmith eds. 1996 } \\
\text { Strange 1996:4-6, 189, 196-198 } \\
\text { Evans 1997:82-87 } \\
\text { Kobrin 1997:155-163 } \\
\text { Rodrik 1997: 1-6, 46-67, 85 } \\
\text { Stryker 1998:7-8, 14-15, 17, 32-33 } \\
\text { Vernon 1998:172-175 } \\
\text { Mosher 1999:25, 35 }\end{array}$ & $\begin{array}{l}\text { Vernon 1971:265-270 } \\
\text { Cox 1987:254-259, 1992:30-31 } \\
\text { Gilpin 1987:389-406 } \\
\text { Stopford and Strange 1991:1-2, 97-136 } \\
\text { Hirst and Thompson 1996:143-194 } \\
\text { Panitch 1996:84-86 } \\
\text { Pierson 1994:1-9 } \\
\text { Sassen 1996:25-30 } \\
\text { Wade 1996 } \\
\text { Albrow 1997:164, 168 } \\
\text { Meyer et al. 1997:153, 157 } \\
\text { Garrett 1998:1-2, 11, 107, 157-158, } 1999 \\
\text { Huber and Stephens 1999 } \\
\text { Held et al. 1999:440 } \\
\text { Fligstein 2001 }\end{array}$ \\
\hline $\begin{array}{l}\text { 4. Is Globality } \\
\text { Different from } \\
\text { Modernity? }\end{array}$ & $\begin{array}{l}\text { Sklair 1991:75-81 } \\
\text { Robertson 1992:27, 138-145, } 1995 \\
\text { Waters } 1995 \\
\text { Castells } 1996 \\
\text { Albrow 1997:4, 33, 95-101, } 144 \\
\text { Kobrin 1997:147-154 } \\
\text { Held et al. 1999:429-431 } \\
\end{array}$ & $\begin{array}{l}\text { Giddens 1990:63-64, 1991:21-22 } \\
\text { Mittelman 1996 } \\
\text { Meyer et al. 1997:150, } 164\end{array}$ \\
\hline $\begin{array}{l}\text { 5. Is a Global } \\
\text { Culture in the } \\
\text { Making? }\end{array}$ & $\begin{array}{l}\text { McLuhan } 1964 \\
\text { McLuhan and Fiore } 1967 \\
\text { Levitt 1983 } \\
\text { Sklair 1991:75-81 } \\
\text { Waters 1995:124-157 } \\
\text { Meyer et al. 1997:162 }\end{array}$ & $\begin{array}{l}\text { Smith } 1990 \\
\text { Mazlish 1993:14, } 16 \\
\text { Friedman 1994 } \\
\text { Appadurai 1996:4, 12, 32-43 } \\
\text { Cox 1996:27 } \\
\text { Portes 1997 } \\
\text { Geertz 1998:107-110 } \\
\text { Keck and Sikkink 1998:32-34, 210-211 } \\
\text { Held et al. 1999:374 } \\
\text { Zelizer 1999 } \\
\text { Inglehart and Baker 2000 }\end{array}$ \\
\hline
\end{tabular}




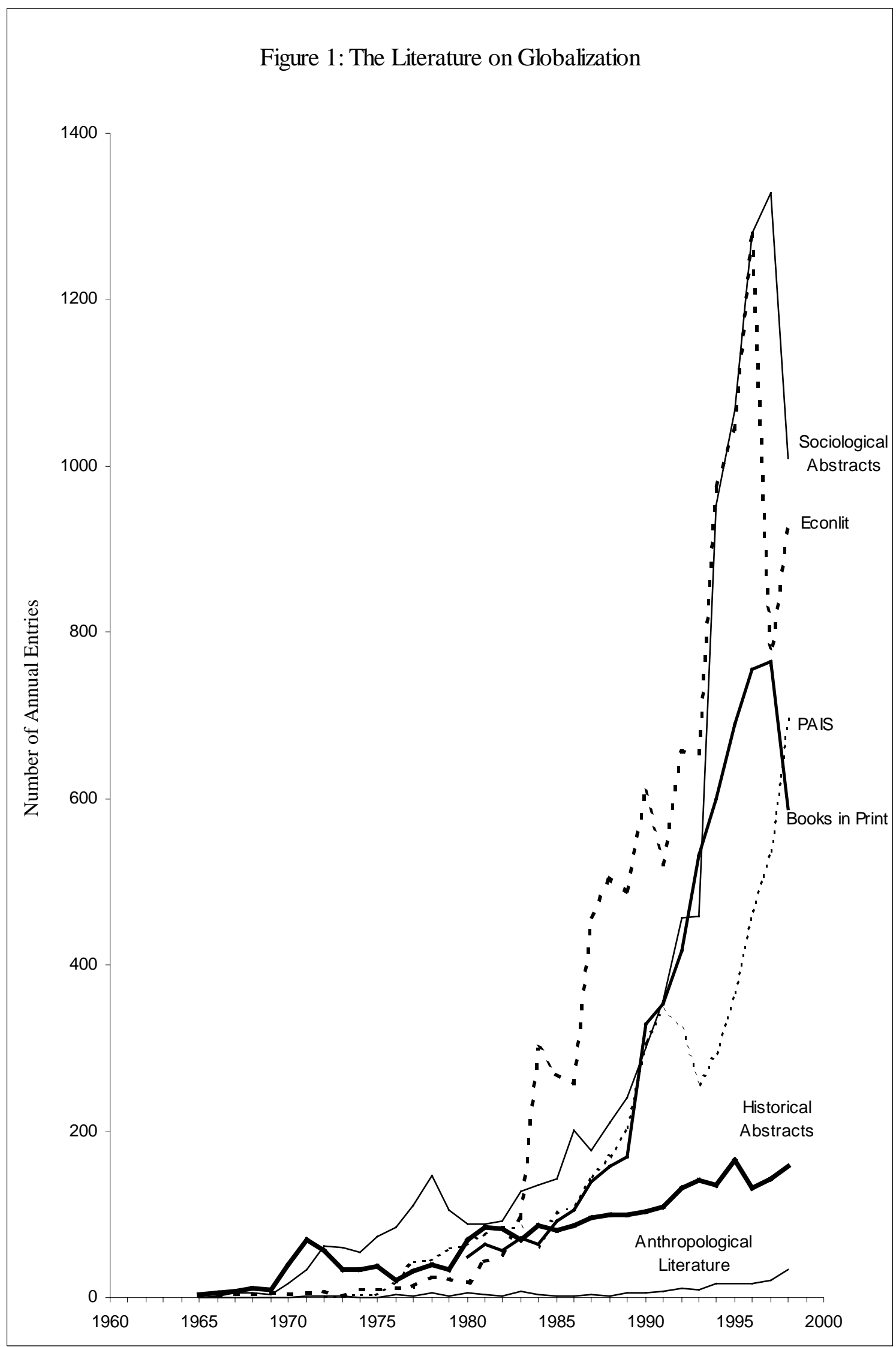


